\title{
Teaching Reform on Art Design Major by Taking High Simulation Management as Standard Project
}

\section{---- Taking Art Design Major Project Teaching Reform in Hainan Qiongtai Normal University as an Example}

\author{
Zhang Ying \\ Qiongtai Normal University, Hainan Haikou, 571127
}

\begin{abstract}
Keywords: Higher vocational college; Art and design major; High simulation management; Project teaching; Project curriculum setting; Education reform
\end{abstract}

\begin{abstract}
This article is aimed at the existing contradictions in arts design curriculum majoring and vocational training direction in higher vocational colleges. Focus on project teaching effect and curriculum organization under industry standard to improve higher vocational art design graduates market employment vitality, professional skills and comprehensive professional quality. Through professional thinking and research, make breakthroughs in tradition professional courses architecture in undergraduate training system. Deconstruct course system again. Determine course credits according to professional post demand and arrange teaching tasks based on project simulation management quantitative indicators. Keep art design major's teaching advantages, and use transverse joint of various majors platform. Implement industry simulation management as standard. It is very necessary to take project course teaching with project teaching workshop course as structure and commercial design industry content as knowledge system.
\end{abstract}

\section{The teaching reform background of arts education in Qiongtai Normal University}

Qiongtai Normal University adheres to the principle of running a school for three hundred years. In the process of national vocational school backbone construction, school leaders attach great importance to discipline education teaching reform, especially Qiongtai Normal University gained national great honor "Advanced Unit for Art Education". It is also a glorious award for art education teaching reform career under the school leadership for many years. The school continues to increase economic input to art design major construction. State financial supported super-large scale art design major practice training base is the fine basis of teaching reform, and the good soil for deepened art design major persistence project course teaching model research on the basis of industry simulation management.

2013 is the key stage of Qiongtai Normal University backbone construction. Arts School responds to school policies, deepens comprehensive reform, strengthens team construction, and continues school education teaching reform themes advocated by backbone school construction. Promote the building of majors and curriculum reform, and truly implement work-learning integrated plans. Reform innovation strength is great, work content range is wide, and thus the professional reform thinking facing is also very deep.

With school leaderships' all-round support, the introduction of high simulation industry management standards is the key to continual promotion of art major teaching project. Art department art design major, through unremitting efforts, gradually builds up a good scientific research team, and makes solid teaching and research base. And art department pursues clear and comprehensive educational reform work with coherent context and sustained. The reform trend is increasingly highlighted. In all the work, department professional construction and major curriculum reform based on work target are unfolding gradually based on comprehensively revised 2013 Art Design Major Talent Training Scheme.

Art Department first chooses art design major as education teaching reform, which is based on higher art design major's market docking degree. It has more explicit industrial production features; and professional curriculum reform based on work target focuses on the new trend of professional 
technical development. Professional course is closely related to the core competence of jobs and occupational qualification standards, and according to professional office post requirements. With reference to relevant professional qualification standards, refine professional ability decomposition layer by layer, boldly carry out curriculum integration and reconstruction; Major construction has clear goal. Actively introduce learning mode combined with productive labor and social practice, as well as teaching modes such as work-study alternation, task driven, project orientation, field work, and explore integration construction of classroom with practice place.

\section{Contradictory thinking of higher vocational art design major curriculum setting}

In recent years, our country's higher vocational education presents unprecedented momentum with clear school-running ideas, increasing enlarged school-running scale increasingly diversified school-running forms. The contradiction between art design major curriculum in higher vocational colleges and market demand is also increasingly obvious. Blindly following art colleges and universities undergraduate teaching plan makes professional setting plan lack social career's epochal character and pertinence, and it does not conform to the goal of higher vocational education personnel training.

This article takes Qiongtai Normal University arts design major group's project teaching reform measures as an example and systematically analyzes the comprehensive research and analysis of Hainan higher vocational colleges' art design major curriculum. It is aiming to the professional thinking of existing contradictions between art design major curriculum in higher vocational colleges and vocational training direction.

We focus on project teaching effect and curriculum organization under industry standard, aiming at enhancing higher vocational art design graduates' employment market vigor, professional skills and comprehensive professional quality.

\section{Project teaching way thinking taking high simulation industry management as a standard}

Increase investment practice of high simulation training link in industry standard construction can improve project organization of teaching process, make art design major teaching practical grasp teaching lifeblood - talent training quality, and demonstrate in the end by the project teaching achievements of artistic design specialized education products and import the theory system to construct characteristic teaching project.

A. Reform the same concept of art design major teaching, adjust the empty content of art design major teaching organization, and enlarge the proportion of commercial design practice teaching. Taking the extremely broad commercial design market of Hainan province international tourism island construction demand as the power, pay efforts to develop higher vocational art design professional students' employment channels, and improve their comprehensive professional quality.

B. Under the severe art design graduates employment situation, it is necessary to take industry simulation management as project teaching research standard, project teaching workshop course as structure, and commercial design industry content as knowledge system. From professional teaching effect and professional needs, adjust course structure, help higher vocational art and design major to better grasp industry rules and social specific requirements for industry professionals.

C. Professional basic course is fully mixed with project phase design task. Dock project output targets with professional required course directly, and coordinate professional development courses and project organization and overall planning, and comprehensive practice ability will fully penetrate artistic design major training practice and teaching at each stage. Make full time factorylike teaching and all-round technology integration. Project research based on industry standard will promote the seamless docking of higher vocational art design major ability training courses and industry requirements.

D. Driven by broader social industry professionals and based on the construction of Hainan international tourism island, rapid commercial design market development, through project research, will explore an education teaching reform path with industry value and effective operation for 
Hainan and national higher vocational art design professional teaching reform and curriculum optimization projects.

\section{Prospect thinking on all-round construction of high simulation management project teaching mode}

Through art and design professional group project course teaching mode construction taking industry simulation management as standard, and project courses opening rate in art design professional group projects teaching system is $95 \%$ or more. After art design major universally implemented the project teaching course, organize professional teaching with standard project course teaching mode taking industry simulation management as standard, art design professional group project simulation training workshop has increased professional training people, and the students who use this project to accept professional training can reach 1000 / year.

Arts design major group constructs industry simulation management project with industry simulation management as standard, the professional teaching and practice teaching demonstration and teaching mode of art and design professional group will substantially increase, and each professional design theory teaching will have repeated exposure and scrutiny in high simulation link of industry management, and industry management standards of work-study integration and university-enterprise cooperation project teaching mode is completed. The most important is to straighten out art design professional group project teaching ideas, and make the industry simulation management mode organization, institutionalization and standardization. Unswervingly adhere to the construction of actual combat type art and design professional training practice base and complete the target of shaping high skills, high quality, and high title applying compound talents.

Every school year, art design professional teachers use project research results and simulation training workshop conditions to complete professional practice ability ascending, improve industry simulation management ability comprehensive quality, finish last quenching of young teachers social industry, and art and design professional team's education teaching reform research ability, at the time, or will receive a leap.

Arts design group can enlarge the major function of industry simulation management project course teaching mode and through professional skill appraisal and vocational skills training, organize professional certification qualification activities oriented social organization, and the conservative estimation of training professional skills appraisal certificate is 200 persons each year.

\section{Difficulties in insisting project teaching with industry simulation management as the standard}

According to the requirement of revised talent training scheme, in the first semester's teaching work in 2013 academic year to 2014 academic year, art design team decoration, electrical art, animation, professional clothing, tourism souvenirs are all in the execution of project teaching, that is a "three steps" work-integrated learning teaching model. The teaching mode, from brewing to stripping forming, arts department has experienced more than two years' professional thinking and professional research: Singapore Nanyang Polytechnic College educational reform in 2011; Suzhou Art \& Design Technology Institute professional training in Suzhou industrial park in 2012; University-enterprise cooperation Weixulong teaching company project platform set up in 2012; 2013 project teaching - "Three Steps" work-integrated learning teaching mode. Capital Normal University demonstrated the scientific nature of curriculum setting logical relationship in project teaching in 2015. Form these, you can see that new personnel training scheme design manuscript is based on very clear educational reform ideas and it is a consistent active context reform measure.

The first semester of 2013 academic year to 2013 academic year is the initial stage of "Three Steps" work-integrated learning teaching mode in art design professional team. As practice teaching reform efforts are from scratch, from fuzzy to clear, from exploration to regular. In the first two months carrying out the teaching practice, art and design professional team discovered several major problems, and at the same time, was faced with a lot of confusion: 
In project course teaching organization, for example, how to grasp professional curriculum recombination and measurement control basis, another is how to build a fair justified, solidary and selfless project teaching team and reasonable teaching quality evaluation system. In other words, how to solve project team members' work performance and incentive mechanism? There are many, many thoughts to solve.

1. The mutual matching problem of project teaching's project package setting and class credits

2. Identification problem of project teaching group's basic management mode and performance

3. Details of project teaching system's primary and secondary relations and teaching organization

4. Management conditions of project teaching practice teaching phase acceptance evidence

5. Identification problem of project teaching course credit allocation and failed or make-up exam subjects

6. Responsibility contract relations of project teaching group and art and design professional faculty and department

7. Displacement measuring of project teaching courses performance and industry standard field results

8. Security settings of project teaching course's labor, support and social security system

9. Project teaching team teamwork labor management files

10. Graduate rebuild standard of project teaching course

11. Booking channels and writing standards of project teaching curriculum notes

12. Project teaching field curriculums' consumables, tools, workshop management

13. Connection and communication between project teaching curriculum organization and school routine teaching management

14. Relations between project teaching achievements, industry profits, and social production

15. Project teaching industry experts, technicians and senior technicians' appraisal system

16. Professional classification management and guarantee system construction in project teaching organization

17. Project teaching organization site requirements, equipment supporting professional condition

18. The docking of project teaching organization and student graduation professional certification system

19. Professional teachers double growth target and implementation in project teaching organization

20. Unified standard of project management and routine management

21. Project curriculum professional research and market investigation, professional internship program

22. Project teaching organization integrated financial management system

23. Project teaching organization's comprehensive personnel management system

24. Project teaching organization's excellent recommendation and upgrade employ system

25. Project teaching transverse joint and actively promote mechanism

26. The deepening and refining of project teaching organization's scientific research subject

27. Professional difference and north-south division of vocational project teaching organization

28. Project teaching organization's electrochemical education model

29. Project teaching organization management's network platform construction plan

30. Project teaching plan's work-integrated learning mode's template formula conclusion

31. Project teaching organization auxiliary product research and art development exhibition center scale

32. Project curriculum course product's patent application and knowledge protection

33. Project teaching practice's other modes reference and international norms and so on

The problems above are only part of initial professional thinking, and there are confusions during the process of implement and we can expect hardness to cope with in the future. The reason is that this is derived from inevitable process and to be gradually clear with the lack of practical experience from industry. We believe that, with comprehensive insist on seeking truth from facts that is project 
teaching reform path of industry simulation management standards. With a lot of hardships and teaching practice in art design major industry, the so-called problems will be the rows of street lamps to the distance.

\section{Conclusion}

A main feature of project teaching system, taking high simulation industry management as standard, is to combine with design principles of higher vocational art design professional project teaching mode, break the original curriculum system, boldly take project unit as teaching team, undertake subcontract teaching task independently, and check the quality of teaching with industry standard.

We think that higher vocational education must change traditional education idea, implement concept innovation, vigorously derive industry management standards, and implement the brand in professional construction. At the same time, in view of the basic task of higher vocational education, train higher technology applied talents; higher vocational education curriculum has goal orientation, content application, and implementation evaluation integrity.

In higher vocational education curriculum system reform, we have to set up modern curriculum and determine course ability view, further deepen the reform of art design professional teaching method, establish curriculum evaluation system with industry management as the standard, and establish a set of effective project teaching mode:

1. How to effectively analyze business design market share organization according to geographical conditions in Hainan and special zone economic characteristics, and take it as basis, reasonably allocate project teaching major courses layout.

2. Take industry real management as evaluation system and evaluation standard, and boldly build project course teaching mode.

3. Break the original professional curriculum organization and group other setting project courses according to project requirements and post ability.

4. Allocate specialized courses credit class hours with industry density.

5. Skills investigate expert group with business leaders and industry elites for project teaching achievement evaluation terminal.

6. Let students in harsh simulation industry environment, whets their wills, strong their minds, build their personality, shape their integrity, improve their skills, and endure their hardships.

7. Eventually establish students' scientific and pragmatic professional view and dedicated professionalism, and become qualified applied talents after graduation as arts design majors.

\section{Fund project}

2014 Hainan higher learning education teaching reform project (Project name: art design major group project course teaching model research in higher vocational colleges taking industry simulation management as the standard; Project approval number: HNJG2014-76)

\section{References}

[1] Cao Xiaoling, Cheng Lin, Shen Shijia. Build practice teaching system in accordance with higher vocational education training objective [J]. Journal of Anhui Electrical Engineering Technical College, 2006, 04.

[2] Zhu Zhiting, He Bin. Analysis on American "2010 National Education Technology Planning" [J]. Journal of Chinese Audio-visual Education, 2011 (6).

[3] Wang Qifeng, Zhang Xiangping, Yang Zhengjun. Higher vocational colleges' two levels teaching management research [J]. Journal of Beijing Politics and Law Vocational College, 2009, 01 . 
[4] Wang Long, Zhou Xiaohuang. The practice mode study of China fine course construction [J]. Journal of Modern Distance Education Research, 2010 (04).

[5] Chen Yuhua, Huang Yuanyuan, Li Xuefeng. Higher vocational education personnel training mode exploration and practice in new period [J]. Journal of Chengdu Aviation Vocational and Technical College, 2004, 04. 